\title{
Detecting financial statements fraud: the evidence from Russia
}

\author{
Natalia V. Feruleva, \\ lecturer of the Department of accounting, analysis and auditing, \\ National Research University Higher School of Economics: \\ Bolshaya Pecherskaya, 25/12, 603155, Nizhny Novgorod, Russia \\ E-mail: nferuleva@hse.ru; natasha.feruleva@mail.ru
}

\section{Maria A. Shtefan,}

associate professor, Head of the Department of accounting, analysis and auditing, Dean of the Faculty of Economics, National Research University Higher School of Economics; Bolshaya Pecherskaya, 25/12, 603155, Nizhny Novgorod, Russia

E-mail: mshtefan@hse.ru

\begin{abstract}
Russian stakeholders of joint stock companies, which shares are not traded on a stock exchange, and limited liability companies need the effective instruments which enable them to detect the facts of financial statement fraud quickly because the financial statement remains the main source of information about the companies' performance for them. Although Institute of Auditors is one of the most reliable tools which identify financial statement manipulations, the costs, connected with audit, are too high and, and as a result, stakeholders have to look for other instruments to distinguish fraudsters, which make an attempt to overestimate or underestimate net assets and financial results, from non-fraudsters. Mathematical model of the American researcher Messod Beneish can be considered as an example of such tools.

The general purpose of this paper is to identify whether it is possible, basing on the Beneish model, to create a new one, which enables to distinguish fraudulent from non-fraudulent financial statements reporting in Russia, and determine the accuracy level of fraud status forecasts made by using this model. In our research we are going to concentrate on identification of companies, which overestimate net assets and financial results.

To obtain the information on the financial ratios included in the model we use financial reports of Russian both non-traded joint stock companies and limited liability firms.

The conclusion can also be drawn that it is possible to develop the fraud detection probit model and linear model (integrated M-Score index), which enabled stakeholders to identify fraud status correctly in 83 and 60\% respectively.

Developing the model we include extra parameters, connected with growth rate of other income to sales ratio and an accounting policy of the company. It was found that fraud risk increases if the company chooses accounting policy according to which administrative costs are charged to core product expenses.
\end{abstract}

Keywords: financial statement fraud, fraud detection, net assets overestimation, financial results overestimation, Russian companies, Beneish model

JEL: M 42 


\section{Introduction}

According to the OECD Principles of Corporate Governance, the firms ought to increase the level of information transparency, making timely and accurate disclosure of data on financial position and performance of the company [OECD Principles of corporate governance, 2004]. High level of information transparency reduces information asymmetry between the companies and their stakeholders and this, in turn, results in lower cost of capital and higher performance. [Ruzhanskaya, 2010; Udaltsov, Tikhonova, 2013]. Despite this fact, the majority of Russian companies, which shares are not traded on stock exchange, avoid revealing additional information about their financial position and income beyond what is required by law, so financial report (balance sheet and income statement) remains the main source of essential information for the stakeholders. However if information presented in financial report does not meet the requirements of completeness and accuracy, it becomes difficult to make financial decisions based on this available data. That is why before making the decisions it seems reasonable for stakeholders to verify that the figures in the reports are not falsified.

It is worth stressing that now falsification of the financial statement is one of the most wide-spread types of cheating in Russia: about $20 \%$ of the companies engaged in economic crime have provided falsified financial statement [Draft on the nationwide survey 'Practice of fighting the corporate fraud' Final Report, 2014]. Moreover, according to the Report to the Nations financial statement fraud leads to the most significant losses in comparison with other types of cheating [Report to the nations on occupational fraud and abuse, 2014]. In connection with such a trend it is essential for stakeholders to employ effective methods of financial fraud detection.

Nowadays Institute of External Auditors remains one of the most reliable tools which identify financial statement manipulation effectively. However not all Russian companies are required by law to be audited. At the same time the development of initiative audit is rather limited because of significant costs. For instance, Kizilov A. reveals that average revenue per the client received by auditors is about 1000000 rubles [Kizilov, Bogataya, 2015]. Furthermore, audit takes time, and this, in turn, affects timeliness of financial decision-making. All these facts point to the need for a new tool which enables stakeholders to identify fraud risks quickly and inexpensively.

It was found that ideas of many researchers [Person, 1995; Summers, Sweeney, 1998; Beneish, 1999; Dechow et al.,
2011] boil down to the development of the mathematical models, determining whether a company provides misleading information about assets, revenue, costs and liabilities, with the help of probit and logistic regressions. To detect falsifications researchers create the specific integrated index, calculated on the basis of the financial ratios. Using financial statement data stakeholders can calculate the value of this index, compare with the benchmark and determine quickly and without any expenses whether there is a risk of financial statement fraud in the company. The accuracy level of Beneish model forecasts was about $89 \%$ and it was the best result in comparison with the results obtained by other researches.

Despite the obvious benefits of such approach, little advance has been achieved in testing the usefulness of this tool in Russia. That is why it is important to assess whether it is possible with the help of Beneish model to distinguish fraudulent from non-fraudulent financial statement reporting in Russia. However, we are not going to simply test the existing Beneish model on sample of Russian firms. It is important to modify Beneish model, taking into account Russian accounting and reporting principles and features of business practice, including widespread ways of financial statement falsification.

\section{Literature review}

The vast majority of authors [Person, 1995; Summers, Sweeney, 1998; Beneish, 1999; Dechow et al., 2011] indicate the importance of the integrated indexes, which would have signaled that financial statement fraud risks are high, but the accuracy level of Beneish model forecasts was the highest. Thus, the accuracy level of Beneish model is $89.5 \%$, whereas the accuracy level of Person model is $71.5 \%$, the accuracy level of Summers and Dechow models is 59.8 and $63.7 \%$ respectively [Person, 1995; Summers, Sweeney, 1998; Beneish, 1999; Dechow et al., 2011].

M. Beneish research can be considered as fundamental in the field of fraud detection models [Beneish, 1999]. He used 8 financial ratios to develop probit-model and, as a result, found the interrelation between them and the facts of fraudulent financial reporting. M. Beneish included in the model days sales in receivable index (DSRI), gross margin index (GMI); asset quality index (AQI), sales growth index (SGI), depreciation index (DEPI), sales and administrative expenses index (SGAI), leverage index (LVGI) and total accruals to total assets (TATA). The explanatory variables are presented in Table 1 (year $t$ refers to the first year in which fraud occurs, year t-1 refers to the previous year).

\section{Table 1.}

Variables of M. Beneish model

\section{Variable Definition Measurement of the variable}

DSRI $\quad \begin{aligned} & \text { Days Sales in } \\ & \text { Receivable Index }\end{aligned} \frac{\text { Receivables }_{t}}{\text { Sales }_{t}} * \frac{\text { Sales }_{t \square 1}}{\text { Receivables }_{t \square 1}}$




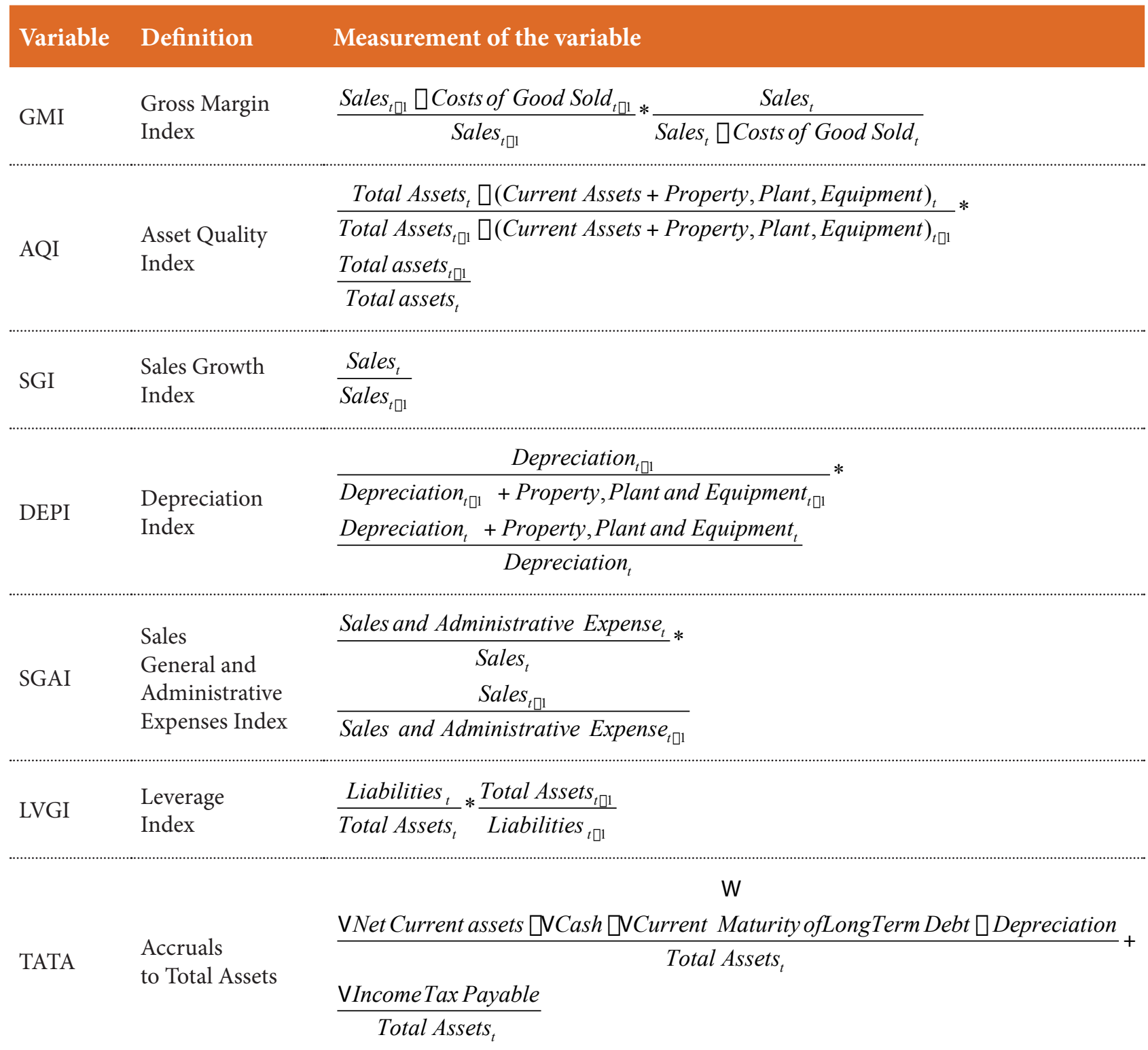

He combined these variables together, basing on financial statements of US companies for the period from 1982 to 1992 (74 manipulators and 2332 non-fraudsters were included in sample), and calculated the financial ratios for each company. After that M. Beneish estimated the coefficients with the help of unweighted probit model and created integrated index (M-Score) for the company. After that he developed a linear equation for M-Score:

$\mathrm{M}$-Score $=-4.840+0.920^{\star} \mathrm{DSRI}+0.528^{\star} \mathrm{GMI}+$ $0.040^{\star} \mathrm{AQI}+0.892^{\star} \mathrm{SGI}+0.115^{\star} \mathrm{DEPI}-0.172 \star \mathrm{SGAI}+$ 4.679* TATA- $0.327^{\star}$ LVGI [Beneish, 1999].

The author provided explanation for the revealed relationships.

For instance, it was anticipated that a dramatic increase in sales and receivables relative to sales may be linked to attempts of revenue falsification, so larger values of these parameters are associated with the higher likelihood of fraud.

M. Beneish also expected a positive relation between GMI and probability of fraud: gross margin deterioration is as- sociated with poor firm's prospects, and that is why can be considered as an incentive for manipulators, who try to hide information about low performance.

As for AQI, the relation is positive because if the company has a lot of assets which measurement is less reliable (intangible assets, other non-current assets and financial investments) the opportunities for financial statement falsification increase significantly.

Decrease in depreciation may indicate the company's attempts to revise groundlessly the useful life of the assets or the depreciation method. As a result, the profit of the company in income statement is exaggerated. So there is a positive correlation between DEPI and probability of falsifications.

Significant decrease in LVGI and SGAI can be connected with understatement of liabilities, sales general expenses and administrative costs. Moreover, such negative changes in SGAI can be also caused by revenue falsification. That is why negative relation between the likelihood of manipulations and these variables was expected. 
As for LVGI we believe that the role of these parameters is doubtful because on the one hand, low level of LVGI may be connected with underestimation of liabilities. On the other hand, higher level of LVGI means that the firm has a lot of creditors and that is why incentives for fraud increase. If we take into account Russian business practice according to which the majority of covenants in loan agreements is financial [Kuvaldina, 2015], it becomes vital to find another ratio that enables to identify fraud with liabilities. For example, when the liabilities of the company are derecognized, the other income of the company increases significantly.

The situation, in that the net assets of the company increase significantly, but cash flow remains unchanged or increase slightly, can also be considered as a case in which risks of fraud is high. So there is a positive relation between TATA and likelihood of financial statement fraud.

These hypotheses were confirmed and M. Beneish found that such variables as Days Sales in Receivable Index, Gross Margin Index, Asset Quality Index, Sales Growth Index and Accruals to Total Assets are significant at the 10\% level. As for the coefficients on the leverage, depreciation, sales and administrative costs, they were not significant [Beneish, 1999].

It was also found that if MS-Score greater than - 1.49 it misclassifies $42 \%$ of fraudsters and $7.6 \%$ of non-fraudsters. If -1.9 is considered as a benchmark, the accuracy level become higher: the percentage of correctly classified fraudsters is $76 \%$ whereas the percentage of correctly classified non-fraudsters is about $82.5 \%$.

The researchers in further studies have already made attempts to test Beneish model and modify it [Harrington, 2005; Roxas, 2011; Tarjo, Herawati, 2015]. They have reconsidered thresholds, excluded factors. In later studies in this field it is suggested to consider -2.22 as a threshold for M. Beneish model, so in this case the risks of defining manipulator as non-manipulator becomes lower. In particular, basing on data of non-fraudsters, provided by $\mathrm{M}$. Beneish, M. Roxas demonstrated benchmarks for each variable included in model and for M-Score (table 2).

\section{Table 2}

The benchmarks for the variables of Beneish model

\begin{tabular}{|c|c|c|c|c|c|c|c|c|c|}
\hline Variable & DSRI & GMI & AQI & SGI & DEPI & SGAI & LVGI & TATA & M-Score \\
\hline Benchmarks & 1.031 & 1.014 & 1.039 & 1.134 & 1.000 & 1.000 & 1.000 & 0.018 & -2.220 \\
\hline
\end{tabular}

In 2005 Harrington C. considered the case of Enron and checked the ability of Beneish model to identify Enron's manipulation. M-Score pointed out that falsification took place in the company [Harrington, 2005], so this instrument of financial statement fraud detection has proven to be effective.

In 2011 M. Roxas continued research in this field, changed the model by excluding SGAI, LVGI and TATA and reassessed it: $\mathrm{M}$-Score $=-6.065+0.823{ }^{*} \mathrm{DSRI}+0.906{ }^{\star} \mathrm{GMI}+$ $0.593{ }^{\star} \mathrm{AQI}+0.717^{\star} \mathrm{SGI}+0.107^{\star} \mathrm{DEPI}$ [Roxas, 2011].

It was found that $\mathrm{M}$-Score less than -2.76 suggests that the company will not be a manipulator, whereas M-Score greater than -2.76 signals that the company is likely to be engaged in financial statement fraud. The accuracy level is about $62 \%$ [Roxas, 2011].

In 2015 Tarjo and Nurul Herawati also checked the ability of M-Score Beneish to identify financial statement fraud. The sample consisted of 70 firms: 35 fraudsters and 35 non-fraudsters. They analyzed the period from 2001 to 2014 , and in their case classification accuracy to detect fraud was $77.1 \%$ (27 of 35 companies that committed fraud). From the 35 non-fraud companies, as many as 28 (80\%) were accurately classified as not committing fraud. Sales growth index was excluded by researchers. DSRI (Days Sales Receivable Index), AQI (Asset Quality Index), and LVGI (Leverage Index) in their research statistically have no significant effect on the detection of financial fraud [Tarjo, Herawati, 2015].
Thus the studies points out that the effectiveness of these instruments is really high, because they correctly identify more than 60 and $80 \%$ of manipulators and non-manipulators respectively in USA [Beneish, 1999; Roxas, 2011; Tarjo, Herawati, 2015]. However the application of M-Score method in Russia is debatable because of the differences in accounting and reporting principles in USA and Russia and the types of financial statement fraud, in which Russian companies often take part.

Currently Russian researchers are interested in application of Beneish model to financial statement fraud detection in Russia [Soboleva, Tolkacheva, 2014]. In spite the fact that in 2014 the accuracy level of forecasts made by using Beneish model for Russian companies has not already been determined, G. Soboleva and D. Tolkacheva made an attempt to identify whether bankrupt firms were engaged in financial statement fraud or not with the help of this model. It was found that in some cases risk of falsification was high and, as a result, such bankrupts can be considered as manipulators [Soboleva, Tolkacheva, 2014]. In 2016 on the sample of 60 Russian companies researchers N. Feruleva and M. Shtefan estimated the accuracy level of forecasts made with the help of Beneish model and revealed that it is about 68\% [Feruleva, Shtefan, 2016].

We presuppose that before applying the model it is important to modify it, taking into consideration that Russian companies may resort to specific methods to falsify financial statement and find out other financial ratios, which 
point to these illegal actions. The Russian researchers Titova and Veshkurtseva [Titova, 2011; Veshkurtseva, 2011] mentioned that in practice Russian companies not only underestimate liabilities, but also overestimate the value of assets in foreign currency and other assets that need to be revaluated. As a result, abnormal growth of other income takes place. Consequently, abnormal changes in other income can be considered as a new factor.

Creating models of financial fraud detection, researchers pay attention mainly to the financial ratios, whereas aspects linked to accounting and reporting principles were not analyzed properly. This appears to be an omission when we create fraud detection model for Russian companies, because according to Russian Standards company has a legal opportunity to hide piece of information from stakeholders due to some aspects of accounting policy. Moreover, not all balance sheet lines in Russia and USA contains the same objects and this aspect should be considered when we determine the quality of assets and calculate asset quality index.

The literature review confirmed that Beneish model is one of instruments of financial statement fraud detection, which effectiveness reached $89.5 \%$ on USA companies' data, and that over the past two decades researches have modified this model and created new models on the base of it. It was also found that in Russia researchers have already made an attempt to apply Beneish model. However researchers have not analyzed yet the opportunity of creation a new model on the base of Beneish model, which enables stakeholders in Russia to distinguish fraudsters from non-fraudsters on the basis of available information.

\section{Problem statement and research hypotheses}

The primary aim of the present study is to identify whether it is possible to distinguish fraudulent from non-fraudulent financial statement reporting in Russia using the integrated index which can be calculated on the base of the available financial statement data. The integrated index includes such variables as days sales in receivable index, gross margin index, modified asset quality index (we take into account aspects, connected with reporting standards), sales growth index, sales and administrative expenses index, income quality index (growth rate of the ratio between other income and sales) and the parameter connected with the accounting policy features. As for accounting policy, in Russia it is possible not to disclose information about administrative costs separately in profit and loss statement if you charge administrative expenses to core product expenses according to accounting principles [Russian Accounting Standard 10 'Costs of organizations', 1999]. As a result, they have an opportunity to hide the data from stakeholders, and in this case the probability of falsification increases.

Hypothesis 1: Employing the integrated index, calculated on the basis of financial ratios, suggested by M. Beneish, income quality index and features of accounting policy, linked to administrative costs, we can distinguish fraudu- lent from non-fraudulent financial statement reporting in Russia.

Hypothesis 2: There is a positive interrelation between the financial statement fraud risk and the income quality index.

Hypothesis 3: The financial statement fraud risk will increase if the company chooses accounting policy according to which administrative costs are charged to core product expenses.

\section{Data}

To check the hypotheses we collect the data on the financial statements submitted under Russian Accounting Standards.

Our sample consists of seventy Russian firms operating in agriculture, manufacture, construction, wholesale and retail trade industries. The sample is also restricted by jointstock companies, which shares are not traded on stock exchange, and limited liability companies. As a consequence, the extent to which the results can be applied will be limited to these firms and the conclusions about trading jointstock companies, companies operating in specific industries such as banking and insurance may differ greatly.

Furthermore, in this research we consider only financial statement fraud aimed at overestimation of the indicators characterizing the financial position and income of the company.

We extract a sample of fraudulent firms from two sources: RosPravosudie and Unified solutions database of the Russian Federation General Jurisdiction Courts. These sources provide the data on lawsuits under section 176.1 of the Russian Criminal Code. If the executive of the company is convicted of providing the bank or other lender false information about the companies' financial position we include this company in the sample. Because in some cases information, which is useful for identification of the fraudster, was removed from official data published by Russian Federation General Jurisdiction Courts we also analyzed the data provided by the media to make sure that the fact of financial statement falsification really took place in the company.

When we collect information about non-fraudulent firms we not only check them through judgments data base but also find positive audit reports to ensure that companies are not engaged in creative accounting. So we have compiled a sample comprising 28 fraudulent and 42 non-fraudulent firms.

Thus, $40 \%$ of the sample are fraudsters, whereas $60 \%$ are non-fraudsters. It is difficult to determine exactly whether this ratio is far from the real ratio between fraudsters and trustworthy firms or not, because of absence of accurate statistics. For instance, some auditors claimed that about $20-25 \%$ of firms have provided falsified financial statement Draft of the nationwide survey 'Practice of fighting the corporate fraud' Final Report, 2014]. However the experts also stressed that often firms make an attempt to hide information that their counterparties are engaged in fraud. More- 
over, auditors have conducted their survey among large firms which have the obligations of auditing according to the Federal Law no. 307 'On Auditing Activities'. That is why we assume that the real share of fraudsters is underestimated. It should be also noted that no auditors claimed that the number of fraudsters is higher than the number of non-fraudsters. So we presuppose that the structure of our sample is appropriate.

The data (balance sheets, income statement, and industry) over the period of 2006-2008 years was obtained from FIRA and SPARK dataset. We consider this period of time for the following reasons:

- information on the facts of falsification of financial statements, revealed in 2012-2014 does not appear in the databases of judgments because of the length of court proceedings;

- according to the statistics, the situation, connected with financial statement fraud, for the period of 2012-2014 was not differ significantly from the situation, connected with financial statement fraud, for the period of 2006-2008 [Economic crime: people, culture and controls. Fourth global economic crime survey, 2008; Draft of the nationwide survey 'Practice of fighting the corporate fraud' Final Report, 2014];

- the data for the period of 2009-2011 should be considered separately, because the risk of falsification in the years of economic crisis and after it becomes higher.

Basing on the information about current and non-current assets, gross profit, turnover, operating costs, other income we calculated the financial ratios included in the integrated index. So we have calculated the ratios, included in Beneish model, such as Days Sales in Receivable Index (DSRI), Gross Margin Index (GMI), Sales Growth Index (SGI); Sales General and Administrative Expenses Index (SGAI) and the modified Asset Quality Index (AQIn). We have modified Asset Quality Index because the measurement of other current assets in Russia is not reliable. For example, Russian companies included in balance sheet line 'Other current assets' shortages, connected with damage and loss of assets, and differed expenses. Thus,

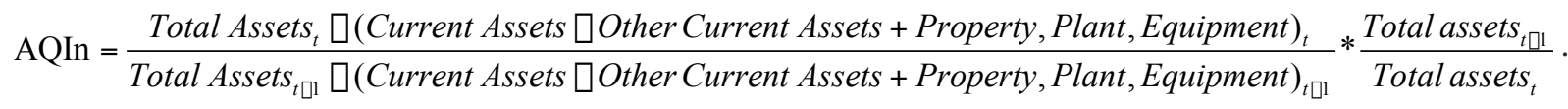

We also have considered the income quality index (growth rate of the ratio between other income and sales (IQI)) and dummy variable ACC, which is equal to 1 if the company chooses accounting policy according to which administrative costs are charged to core product expenses.

The descriptive statistics of the variables included into models is presented in table 3.

Table 3. Summary of descriptive statistics for Russian companies (2006-2008)

\begin{tabular}{|c|c|c|c|c|c|c|c|}
\hline Variable & DSRI & GMI & AQIn & SGI & SGAI & IQI & $\mathrm{ACC}$ \\
\hline Median & 0.935 & 0.999 & 1.000 & 1.212 & 1.000 & 0.883 & 1.000 \\
\hline Std.Dev. & 1.873 & 4.387 & 4776.074 & 182.344 & 4.56735 & 46.625 & 0.448 \\
\hline Minimum & 0.091 & -1.050 & 0.000 & 0.110 & 0.009 & 0.000 & 0.000 \\
\hline Maximum & 10.781 & 34.834 & 30010.000 & 1527.000 & 38.000 & 308.085 & 1.000 \\
\hline Mean & 1.520 & 1.881 & 875.110 & 24.018 & 1.723 & 11.286 & 0.729 \\
\hline
\end{tabular}

It seems reasonable to demonstrate descriptive statistic of the variables for non-fraudsters and fraudsters separately (table 4, table 5).

Table 4. Summary of descriptive statistics for Russian fraudsters

\begin{tabular}{|c|c|c|c|c|c|c|c|}
\hline Variable & DSRI & GMI & AQIn & SGI & SGAI & IQI & $\mathrm{ACC}$ \\
\hline Median & 1.068 & 1.090 & 1.000 & 1.377 & 1.000 & 0.921 & 1.000 \\
\hline Std.Dev. & 2.534 & 6.718 & 7438.042 & 288.030 & 7.155 & 71.890 & 0.315 \\
\hline Minimum & 0.091 & 0.000 & 0.000 & 0.110 & 0.009 & 0.008 & 0.000 \\
\hline Maximum & 10.781 & 34.834 & 30010.000 & 1527.000 & 38.000 & 308.085 & 1.000 \\
\hline Mean & 1.980 & 2.750 & 2185.972 & 58.107 & 2.776 & 25.669 & 0.893 \\
\hline
\end{tabular}


Table 5

Summary of descriptive statistics for Russian non-fraudsters

\begin{tabular}{|c|c|c|c|c|c|c|c|}
\hline Variable & DSRI & GMI & AQIn & SGI & SGAI & IQI & $\mathrm{ACC}$ \\
\hline Median & 0.904 & 0.986 & 0.985 & 1.191 & 1.000 & 0.883 & 1.000 \\
\hline Std.Dev. & 1.198 & 1.348 & 0.915 & 0.635 & 0.371 & 4.423 & 0.492 \\
\hline Minimum & 0.172 & -1.050 & 0.001 & 0.395 & 0.237 & 0.000 & 0.000 \\
\hline Maximum & 7.813 & 7.990 & 4.354 & 4.239 & 2.644 & 27.840 & 1.000 \\
\hline Mean & 1.213 & 1.301 & 1.202 & 1.292 & 1.0216 & 1.697 & 0.619 \\
\hline
\end{tabular}

It is obvious that deviation of all variables for manipulators is higher than deviation of all variables for non-manipulators. These deviations appear just because of attempts to falsify financial statement data.

Correlation matrix is presented in table 6 .

Table 6

Correlation matrix

\begin{tabular}{|c|c|c|c|c|c|c|c|}
\hline Variable & DSRI & GMI & AQIn & SGI & SGAI & IQI & $\mathrm{ACC}$ \\
\hline DSRI & 1.000 & -0.041 & -0.109 & -0.093 & 0.093 & 0.067 & -0.244 \\
\hline GMI & -0.041 & 1.000 & -0.016 & -0.042 & -0.071 & -0.043 & 0.067 \\
\hline AQIn & -0.109 & -0.016 & 1.000 & -0.020 & -0.041 & 0.528 & 0.113 \\
\hline SGI & -0.093 & -0.042 & -0.020 & 1.000 & -0.02 & -0.028 & 0.077 \\
\hline SGAI & 0.093 & -0.071 & -0.041 & -0.02 & 1.000 & 0.027 & 0.035 \\
\hline IQI & 0.067 & -0.043 & 0.528 & -0.028 & 0.027 & 1.000 & 0.079 \\
\hline $\mathrm{ACC}$ & -0.244 & 0.067 & 0.113 & 0.077 & 0.035 & 0.079 & 1.000 \\
\hline
\end{tabular}

\section{Methods}

To solve the problems arising in the study the variety of methods are applied.

Basing on Russian companies data we calculated the financial ratios included in the Beneish model for each company. Lack of data on depreciation and amortization made us to exclude TATA and DEPI. Because the majority of Russian companies do not disclose information about amortization the model, including such parameters, will be useless for stakeholders who have no access to internal data. We believe that exclusion of TATA and DEPI doesn't cause deterioration of model performance, because Russian companies avoid revising useful life of assets and depreciation method. Such behavior connected with the fact that under Russian Accounting Standard it is possible to change depreciation method and useful life of property, plant and equipment only in some cases [Russian Accounting Standard 6 'Accounting of property, plant and equipment', 2001]. As for variable AQI, it should be replaced by AQIn, and this enables us to take into consideration the feature of financial reporting in Russia linked to the fact that the measurement of other current assets in Russia is not reliable. It is also worth stressing that in some cases the denominator of the AQIn variable was zero because assets in the pre- vious year consisted of current assets and property, plant and equipment only. In spite of the fact that in these cases the AQIn was not defined we set its value to one instead of treating the observations as missing. The same approach was used by M. Beneish [Beneish, 1999].

Moreover, in some cases the denominator of the SGAI variable was zero because some companies don't have any sales and administrative expense. Despite the fact that in these cases the SGAI was not defined, we also set its value to one instead of treating the observations as missing.

We mentioned earlier that we should exclude LVGI, because of ambiguity of influence of this parameter. On the one hand, low level of LVGI may be connected with underestimation of liabilities. On the other hand, higher level of LVGI means that the firm has a lot of creditors and that is why incentives for fraud increase. According to Russian business practice the majority of covenants in loan agreements are financial [Kuvaldina, 2015], and this, in turn, means that companies which take more loans are under pressure and have strong incentive to concentrate on creative accounting. As a consequence, this parameter should be replaced by another one. Underestimation of liabilities, connected with an attempt to derecognize liabilities, may lead to growth of other income. So we ought to create the ratio, which reflects such changes. 
Sharp increase in other income may appear if the firm is engaged in overestimation of the value of assets in foreign currency and other assets that need to be revaluated. However, other income increases if the company expands its activity. In order to eliminate the influence of expansion it seems reasonable to consider ratio between other income and sales instead of other income. When other income rises dramatically and this effect is not caused by expansion, enormous changes in ratio between other income and sales will take place. Thus, we have included in the model the income quality index (IQI):

$$
\mathrm{IQI}=\frac{\text { Otherincome }_{t}}{\text { Sales }_{t}} * \frac{\text { Sales }_{t \square 1}}{\text { Other income }_{t \square 1}},
$$

If a firm did not have any other sources of income IQI variable was equal to one.
As for the dummy variable ACC, it is equal to 1 if the company chooses accounting policy according to which administrative costs are charged to core product expenses. Firstly, to test the hypotheses we employed probit model and basing on our sample estimated coefficients for the model.

Thus, we have:

$$
\mathrm{P}\left(\text { fraud }_{i}=1\right)=\mathrm{F}()=\square_{\square}^{\stackrel{\tilde{o}_{i}^{\prime} \mathrm{b}}{\sqrt{2} * \mathrm{p}}} e^{\square-\frac{1}{2} * t^{2} d t}
$$

where $i$-number of the company in the sample, - real fraud status (1-if the company committed financial statement falsification;0-if the company is non-manipulator).

It is supposed that latent variable fraud ${ }^{*}$, propensity for fraud, exists.

The equation for latent variable:

$$
\operatorname{fraud}_{i} *=\mathrm{b}_{1}+\mathrm{b}_{2} * D S R I_{i}+\mathrm{b}_{3} * G M I_{i}+\mathrm{b}_{4} * A Q I n_{i}+\mathrm{b}_{5} * S G I_{i}+\mathrm{b}_{6} * S G A I_{i}+\mathrm{b}_{7} * I Q I_{i}+\mathrm{b}_{8} * A C C_{i}+\mathrm{e}_{i} \text {. }
$$

The parameters in probit-model are estimated by the method of maximum likelihood, and it is supposed that is normally distributed.

On the basis of the probit-model it is also possible to create M-Score index. So the linear equation for integrated index M-Score was found:

$$
\text { MワScore }=\mathrm{b}_{1}+\mathrm{b}_{2} * D S R I_{1}+\mathrm{b}_{3} * G M I+\mathrm{b}_{4} * A Q I n+\mathrm{b}_{5} * S G I+\mathrm{b}_{6} * S G A I+\mathrm{b}_{7} * I Q I+\mathrm{b}_{8} * A C C \text {. }
$$

The same approach was used by M. Roxas. Furthermore, despite the fact that M Beneish considered various models, as a result the linear equation for the M-Score index became the most widespread.

In order to check the first hypothesis we used likelihood ratio test (LR-test) to prove that the regression is significant. After that we made forecasts for the probability of financial statement fraud in each company. If it is higher than 50\% we determine that the risk of financial statement fraud is high, if it is lower than $50 \%$ the risk is low. In other cases, we supposed that fraud status is not defined. Then we determined the accuracy level (share of correct forecasts) and, employing a comparative approach, we matched it with 50\%. If the accuracy level of our model is not lower than $50 \%$ it can be considered as an effective tool for fraud detection.

We also used z-test to identify whether the variables are significant or not. In particular, we employed this test to check the second and the third hypotheses.

Secondly, we revised the benchmark for indexes, included in the M-Score, basing on average of included in models finan-

\begin{tabular}{|c|c|c|c|c|c|c|c|}
\hline Variable & DSRI & GMI & AQIn & SGI & SGAI & IQI & ACC \\
\hline Benchmarks & 1.213 & 1.301 & 1.202 & 1.292 & 1.022 & 1.697 & 0.729 \\
\hline
\end{tabular}
cial ratios for Russian trustworthy companies (Table 7) and estimated the threshold for M-Score. As for the benchmark for dummy variable, we have chosen average for all companies because data on this parameter is not falsified.

Table 7. The benchmarks for the variables of model

Taking into account new thresholds, we made forecasts: if M-Score for the company is higher than the threshold the risk that we deal with a fraudster is high. Then we estimated the accuracy level and compare it with the accuracy level obtained by M. Beneish.

It is important to highlight that benchmarks for Russian companies is higher than the benchmarks for American companies. This may be caused, in particular, by the fact that Russian companies do not create reserves for receivables and assets of Russian companies are not tested for impairment. For instance, in Accounting Standard 14 'Accounting of intangible assets' there is no clear method for the impairment test conducting. Moreover, conducting the impairment test is not obligatory for Russian companies.

Higher growth rate of Russian companies' revenue is also understandable. The Russian economy refers to the economies of rapidly - developing type, in which revenue growth higher than the same indicator calculated for the advanced economies [Ernst \& Young, Competing for growth: how business is growing beyond boundaries, 2011]. 


\section{Results}

With the help of maximum likelihood method we estimate the parameters in probit-models on the basis of our sample.

Table 8 presents the results for the model.

Table 8

Regression results for M. Beneish model

\begin{tabular}{|c|c|}
\hline Variable & Coefficient \\
\hline const & $-2.824(0.821)^{\star * *}$ \\
\hline DSRI & $0.305(0.133)^{\star *}$ \\
\hline GMI & $0.051(0.051)$ \\
\hline AQIn & $0.126(0.145)$ \\
\hline SGI & $0.273(0.265)$ \\
\hline SGAI & $0.248(0.408)$ \\
\hline IQI & $0.006(0.027)$ \\
\hline ACC & $1.202(0.550)^{\star *}$ \\
\hline $\mathrm{N}$ & 70 \\
\hline $\operatorname{LR}$ chi2 $(7)$ & 34.820 \\
\hline Prob > chi2 & 0.000 \\
\hline
\end{tabular}

Standard errors in parentheses:

${ }^{*} p<0.10 ;{ }^{* *} p<0.05 ;{ }^{* *} p<0.01$
The LR test proves that this model is better than a model that contains only a constant as explanatory variable.

As it was expected all coefficients in the model are positive, so larger value of these ratios is associated with the higher likelihood of fraud.

The variables with the exception of constant, DSRI and ACC are not significant. Days Sales in Receivable Index is significant at $5 \%$, whereas constant is significant at $1 \%$.

The hypothesis that there is a positive interrelation between the financial statement fraud risk and the income quality index was not confirmed: the coefficient is positive, but not significant even at $10 \%$. But we will not exclude this variable.

As it was expected the financial statement fraud risk will increase if the company chooses accounting policy according to which administrative costs are charged to core product expenses. So if the company does not disclose information about these costs separately in profit and loss statement the probability of falsification increases.

We also made forecasts and in 26 cases the fraud status for the companies, which have falsified financial statements, was identified correctly. The whole accuracy level for this model is $83 \%$ (61\% for fraudsters and $98 \%$ for non-manipulators).

Then we revised benchmarks for model (table 9).

Table 9

Benchmarks for Russian companies

\begin{tabular}{|c|c|c|c|c|c|c|c|c|c|}
\hline Variable & DSRI & GMI & AQIn & SGI & SGAI & IQI & $\mathrm{ACC}$ & const & $\begin{array}{l}\text { New } \\
\text { M-Score }\end{array}$ \\
\hline Coefficient & 0.305 & 0.051 & 0.126 & 0.273 & 0.248 & 0.006 & 1.202 & -2.824 & - \\
\hline Benchmarks & 1.213 & 1.301 & 1.202 & 1.292 & 1.022 & 1.697 & 0.729 & & -0.744 \\
\hline
\end{tabular}

The linear equation for M-Score index:

$\mathrm{M}$-Score $=2.824+0.305^{\star} \mathrm{DSRI}+0.051^{\star} \mathrm{GMI}+0.126^{\star} \mathrm{AQIn}+0.273^{\star} \mathrm{SGI}+0.248^{\star} \mathrm{SGAI}+0.006^{\star} \mathrm{IQI}+1.202^{\star} \mathrm{ACC} .(6)$

M-Score $($ threshold $)=-2.824+0.305{ }^{\star} 1.213+0.051^{\star} 1301+01266^{\star} 1202+0273{ }^{\star} 1292+0248{ }^{\star} 1022+0006{ }^{\star} 1697+$ $1202 * 0729=-0.744$.

We calculated M-Score for each company included in the sample and determined whether M-Score lower or higher than -0.744. Under the rule we identified the fraud status of firms and compared it with the real fraud status.

Tables 10-11 present the results of M-Score calculation for companies, engaged in financial statement fraud, and for non-fraudsters. It was revealed that the model correctly predicted 42 of the 70 companies' fraud status.

Table 10

Results of M-Score measurement for fraudsters

\begin{tabular}{|c|c|c|c|c|c|c|c|c|}
\hline \multirow{2}{*}{ Name of the company } & \multicolumn{8}{|c|}{ Variables } \\
\hline & DSRI & GMI & SGI & SGAI & $\mathrm{ACC}$ & IQI & AQIn & M-Score \\
\hline $\begin{array}{l}\text { Abinskaja peredvizhnaja } \\
\text { mehanizirovannaja kolonna }\end{array}$ & 0.136 & 0.000 & 1527.0 & 1.000 & 1.000 & 0.820 & 106.500 & 428.962 \\
\hline Bagaon & 0.520 & 1.613 & 1.594 & 1.178 & 1.000 & 308.085 & 26791.88 & 3376.972 \\
\hline
\end{tabular}




\begin{tabular}{|c|c|c|c|c|c|c|c|c|}
\hline \multirow{2}{*}{ Name of the company } & \multicolumn{8}{|c|}{ Variables } \\
\hline & DSRI & GMI & SGI & SGAI & $\mathrm{ACC}$ & IQI & AQIn & M-Score \\
\hline Delikat & 1.136 & 1.290 & 1.323 & 0943 & 0.000 & 3.641 & 1.258 & -1.636 \\
\hline Dormashservis & 10.781 & 0.029 & 0.110 & 10.345 & 0.000 & 84.379 & 1.015 & 3.695 \\
\hline Krastjeks & 3.813 & 0.210 & 0.483 & 3.788 & 1.000 & 2.059 & 0.663 & 0.719 \\
\hline Mius & 0.408 & 0.240 & 0.915 & 1.000 & 1.000 & 0.098 & 0.927 & -0.870 \\
\hline $\begin{array}{l}\text { Nal'chikskij } \\
\text { mashinostroitel'nyj zavod }\end{array}$ & 1.905 & 2.631 & 0.565 & 1.000 & 1.000 & 0.421 & 0.920 & -0.386 \\
\hline Otkrytyj mir & 1.678 & 4.306 & 1.992 & 1.438 & 1.000 & 11.345 & 3.677 & 0.541 \\
\hline Ralli & 0.212 & 34.834 & 2.780 & 0.009 & 1.000 & 1.000 & 1.000 & 1.112 \\
\hline Torgservis & 5.716 & 0.805 & 1.443 & 1.198 & 1.000 & 1.460 & 0.854 & 0.970 \\
\hline OJL- SERVIS & 0.142 & 1.188 & 3.228 & 1.138 & 1.000 & 0.209 & 1.000 & -0.227 \\
\hline Stavropol'ski & 1.917 & 1.304 & 0.763 & 2.340 & 1.000 & 7.527 & 12.476 & 1.435 \\
\hline Dorservis & 2.241 & 0.743 & 2.218 & 0.097 & 1.000 & 0.599 & 0.444 & -0.211 \\
\hline Sibmebel' & 0.828 & 1.089 & 1.408 & 0.900 & 1.000 & 0.010 & 0.000 & -0.706 \\
\hline Shahtosnab & 1.680 & 2.015 & 0.749 & 0.471 & 1.000 & 1.951 & 1966.000 & 247.042 \\
\hline $\begin{array}{l}\text { SPPT I SR } \\
\text { "Specgidrotehstroj" }\end{array}$ & 0.252 & 0.630 & 2.784 & 1.000 & 1.000 & 228.808 & 2297.000 & 290.290 \\
\hline Elm & 7.257 & 0.192 & 1.045 & 1.452 & 0.000 & 1.000 & 0.368 & 0.097 \\
\hline SUAR & 1.290 & 0.926 & 1.345 & 1.000 & 1.000 & 0.615 & 1.000 & -0.436 \\
\hline Avgust-91 & 1.147 & 0.919 & 1.125 & 0.964 & 1.000 & 0.842 & 1.932 & -0.431 \\
\hline $\begin{array}{l}\text { Lermontovskij Okonnyj } \\
\text { Zavod }\end{array}$ & 1.000 & 12.766 & 49.780 & 1.000 & 1.000 & 0.008 & 1.000 & 13.298 \\
\hline Torgovaja firma Fort & 0.856 & 0.979 & 1.033 & 0.988 & 1.000 & 3.052 & 1.292 & -0.603 \\
\hline Biohem-Jug & 0.235 & 0.912 & 2.395 & 38.000 & 1.000 & 1.000 & 1.000 & 8.706 \\
\hline Vekas & 0.923 & 1.167 & 1.643 & 1.206 & 1.000 & 0.457 & 1.000 & -0.405 \\
\hline TD «IRJeNA» & 0.254 & 1.451 & 1.142 & 0.279 & 1.000 & 0.757 & 30010.00 & 3780.175 \\
\hline Prostor & 0.108 & 2.075 & 1.468 & 1.000 & 1.000 & 0.199 & 1.000 & -0.707 \\
\hline Severmazservis & 5.209 & 0.466 & 0.757 & 2.130 & 1.000 & 58.124 & 1.000 & 1.200 \\
\hline Sladkij kljuch & 0.091 & 1.090 & 14.880 & 1.000 & 1.000 & 0.020 & 1.000 & 2.898 \\
\hline $\begin{array}{l}\text { Juzhno-russkaja } \\
\text { prodovol"stvennaja } \\
\text { kompanija }\end{array}$ & 3.699 & 1.141 & 1.038 & 0.850 & 1.000 & 0.267 & 1.000 & 0.186 \\
\hline
\end{tabular}




\section{Table 11}

Results of M-Score measurement for non- fraudsters

\begin{tabular}{|c|c|c|c|c|c|c|c|c|}
\hline \multirow{2}{*}{ Name of the company } & \multicolumn{8}{|c|}{ Variables } \\
\hline & DSRI & GMI & SGI & SGAI & $\mathrm{ACC}$ & IQI & AQIn & M-Score \\
\hline $\begin{array}{l}\text { Molochnyj kom'inat } \\
\text { Stavropol'skij }\end{array}$ & 0.769 & 0.964 & 1.325 & 1.179 & 0.000 & 1.005 & 1.409 & -1.703 \\
\hline Okeanpribor & 1.514 & 1.440 & 0.857 & 1.000 & 1.000 & 27.840 & 0.846 & -0.331 \\
\hline $\begin{array}{l}\text { Pticekombinat } \\
\text { Stavropol'skij }\end{array}$ & 0.172 & 0.918 & 1.396 & 0.951 & 0.000 & 1.000 & 0.831 & -1.997 \\
\hline Avitek & 0.510 & 1.759 & 1.003 & 0.626 & 0.000 & 0.515 & 0.985 & -2.022 \\
\hline $\begin{array}{l}\text { Nezavisimaja } \\
\text { jenergosbytovaja } \\
\text { kompanija }\end{array}$ & 0.676 & 0.990 & 1.870 & 1.000 & 1.000 & 0.781 & 1.832 & -0.371 \\
\hline BZRK & 0.301 & 1.098 & 1.423 & 0.676 & 0.000 & 0.767 & 1.890 & -1.877 \\
\hline Shhigrovskaja MTS & 0.799 & 2.291 & 0.828 & 1.000 & 1.000 & 1.274 & 1.151 & -0.635 \\
\hline $\begin{array}{l}\text { Agropromyshlennaja firma } \\
\text { «Rossija» }\end{array}$ & 7.813 & 7.990 & 1.614 & 1.000 & 0.000 & 0.920 & 0.091 & 0.672 \\
\hline $\mathrm{MiR}$ & 0.853 & -1.050 & 1.180 & 2.644 & 1.000 & 1.308 & 0.985 & -0.306 \\
\hline Rjazanagrohim & 0.875 & 0.867 & 1.202 & 0.891 & 1.000 & 0.751 & 0.997 & -0.632 \\
\hline Teplovskaja DORMPK & 0.602 & 1.007 & 2.203 & 1.000 & 1.000 & 0.598 & 0.812 & -0.432 \\
\hline $\begin{array}{l}\text { Morgaushskij dorozhno- } \\
\text { tehnicheskij servis }\end{array}$ & 1.290 & 0.905 & 1.029 & 1.000 & 1.000 & 0.870 & 1.000 & -0.522 \\
\hline Vurnarydorstroj & 0.668 & 0.573 & 2.054 & 1.000 & 1.000 & 0.348 & 0.188 & -0.555 \\
\hline Burejagjesstroj & 0.945 & -0.227 & 1.323 & 1.000 & 1.000 & 0.898 & 0.708 & -0.642 \\
\hline Sibstrojservis & 1.625 & 0.362 & 0.721 & 1.000 & 1.000 & 1.317 & 1.049 & -0.523 \\
\hline Chuvashpechat' & 0.925 & 1.032 & 1.296 & 1.105 & 1.000 & 1.497 & 0.883 & -0.539 \\
\hline Social'naja sfera & 0.741 & 0.975 & 1.089 & 1.000 & 1.000 & 1.906 & 2.128 & -0.521 \\
\hline Prodtorg & 2.354 & 0.784 & 0.439 & 1.555 & 0.000 & 1.715 & 1.000 & -1.424 \\
\hline Nizhnekamsk-Lada_servis & 0.840 & 2.052 & 2.150 & 0.660 & 0.000 & 1.033 & 0.662 & -1.623 \\
\hline Tambovkniga & 1.656 & 1.052 & 0.983 & 1.032 & 1.000 & 0.315 & 1.000 & -0.411 \\
\hline Pechat' & 1.215 & 1.015 & 1.148 & 1.117 & 0.000 & 0.705 & 0.948 & -1.688 \\
\hline $\begin{array}{l}\text { Astrahanskij central'nyj } \\
\text { univermag }\end{array}$ & 1.097 & 1.016 & 0.977 & 1.012 & 0.000 & 0.110 & 0.820 & -1.816 \\
\hline $\begin{array}{l}\text { Rosneft' - } \\
\text { Murmansknefteprodukt }\end{array}$ & 1.641 & 0.792 & 0.978 & 1.262 & 0.000 & 0.870 & 0.885 & -1.586 \\
\hline Sosnovoborskaja torgovlja & 1.937 & 0.544 & 0.496 & 1.532 & 1.000 & 10.799 & 0.970 & -0.301 \\
\hline Lenoblagropromhimija & 0.882 & 2.627 & 1.214 & 1.097 & 1.000 & 1.214 & 1.000 & -0.482 \\
\hline Kondopogalestorg & 1.877 & 1.015 & 1.127 & 0.862 & 0.000 & 0.053 & 0.798 & -1.577 \\
\hline JeMAljans & 0.843 & 0.666 & 2.191 & 0.625 & 0.000 & 0.327 & 0.698 & -1.690 \\
\hline Torgovyj centr & 0.240 & 1.930 & 4.239 & 0.605 & 1.000 & 1.000 & 1.000 & -0.011 \\
\hline Kurskmetaltorg & 0.990 & 0.805 & 1.091 & 1.307 & 1.000 & 1.000 & 0.648 & -0.569 \\
\hline Berezka v Luzhnikah & 0.828 & 1.310 & 1.857 & 0.684 & 1.000 & 0.316 & 4.354 & -0.076 \\
\hline JeFKO Produkty ritanija & 3.050 & 2.187 & 0.395 & 0.298 & 0.000 & 0.236 & 1.001 & -1.473 \\
\hline Tjumen’obshhepit & 0.181 & 0.912 & 1.032 & 1.133 & 0.000 & 0.911 & 3.983 & -1.652 \\
\hline $\begin{array}{l}\text { Neftekamskij } \\
\text { hlebokombinat }\end{array}$ & 1.136 & 1.108 & 1.211 & 0.864 & 1.000 & 0.678 & 1.300 & -0.506 \\
\hline
\end{tabular}




\begin{tabular}{|c|c|c|c|c|c|c|c|c|}
\hline \multirow{2}{*}{ Name of the company } & \multicolumn{8}{|c|}{ Variables } \\
\hline & DSRI & GMI & SGI & SGAI & ACC & IQI & AQIn & M-Score \\
\hline Tander & 1.100 & 0.960 & 1.370 & 1.046 & 1.000 & 0.955 & 2.406 & -0.295 \\
\hline Rybnovskaja sht & 0.829 & 2.136 & 1.277 & 0.237 & 1.000 & 1.234 & 0.980 & -0.722 \\
\hline Kozlovskaja sel'hozhimija & 1.965 & 4.516 & 0.930 & 1.209 & 1.000 & 1.000 & 1.000 & -0.107 \\
\hline $\begin{array}{l}\text { Molochnyj zavod } \\
\text { Ussurijskij }\end{array}$ & 0.518 & 1.297 & 1.299 & 0.943 & 0.000 & 0.733 & 3.591 & -1.555 \\
\hline ATJe-1 & 1.357 & 0.529 & 1.262 & 1.000 & 1.000 & 0.519 & 0.001 & -0.585 \\
\hline Agrotrak & 0.623 & 0.707 & 0.898 & 1.100 & 0.000 & 0.426 & 1.678 & -1.866 \\
\hline Bortorg & 0.619 & 0.917 & 1.138 & 1.104 & 1.000 & 0.000 & 0.263 & -0.769 \\
\hline Apteka 220 & 0.944 & 0.897 & 0.837 & 1.356 & 1.000 & 0.647 & 0.967 & -0.598 \\
\hline Kabbaltorgodezhda & 1.145 & 0.982 & 1.330 & 1.198 & 1.000 & 0.896 & 0.732 & -0.465 \\
\hline
\end{tabular}

It was found that in 26 cases the fraud status for the companies, which have falsified financial statements, was identified correctly. The number of unsubstantiated assumptions about fraud is equal to 26 . So the whole accuracy level for the model is $60 \%$ ( $93 \%$ for fraudsters and $38 \%$ for non-manipulators).

Then we compare the accuracy level of the forecast received due to the new M-Score with the forecast accuracy of the new binary model (Table 12).

Table 12

Forecast accuracy

\section{Model}

\section{Accuracy level,\%}

Fraudsters $\quad$ Non-fraudsters

98

38
Whole

83 for Russian companies)

New model (forecasts obtained with the help of M-Score index for Russian companies)
61

93
60
The majority $(83 \%)$ of the new probit-model forecasts is correct, so this model enables to distinguish Russian fraudsters from non-fraudsters. However, these results were obtained on the sample which was also used when we estimated the parameters for the model, so the forecast accuracy is overestimated. Furthermore, the forecasts are too optimistic: in 39\% cases fraudsters were not identified. It is impossible to ignore this problem because greater risk lies in the fact that we recognize fraudsters as trustworthy companies.

Despite the fact that accuracy level of forecasts obtained with the help of new M-Score is lower than the accuracy level of the other models, it also seems reasonable to employ this model to detect financial statement fraud in Russia. We should stress that the number of correct predictions, generated with the help of the new model, for fraudulent companies is higher. At the same time more than $60 \%$ of non-manipulators were recognized as fraudsters. The risk of recognition a trustworthy Russian company as fraudster is high. So this model will be especially helpful for risk averse investors.
This, in turn, proves that the model needs to be improved. In order to provide Russian stakeholders with effective methods of financial statement fraud detection it seems reasonable to specify variables in models taking into account another ways which Russian companies can use in order to falsify financial statement. We presuppose that in further studies it makes sense to include the parameters connected with external factors which have influence on the company such as level of crime in the region and the features of industry in which company operates.

\section{Conclusion}

The present study demonstrates that basing on the Beneish model, it is possible to develop the model, which enables to distinguish fraudulent from non-fraudulent financial statement reporting in Russia. In the model we include extra parameters, connected with growth rate of other income to sales ratio and an accounting policy of the company.

It was found that the risk of falsification increases if the company chooses accounting policy according to which administrative costs are charged to core product expenses. 
This parameter was significant at 5\%. The risk of fraud also rises if other income to sales ratio increases but this interrelation is not significant even at $10 \%$.

The accuracy level of forecasts made on the basis of probit model estimated on Russian companies' data is $83 \%$. The performance decreased when we calculated the M-Score index with the help of linear equation, compared it with the threshold and made forecasts on fraud status. The share of correct predictions for fraudulent companies is about $98 \%$, whereas share of correct predictions for trustworthy companies is only $31 \%$.

So the model need to be improved and it would be essential to include in the models some external factors, which have influence on the firms. In further investigations we ought to analyze another ways which Russian companies use in order to falsify financial statement and identify other financial ratios, which point to these illegal actions.

The results would be helpful to stakeholders when they make financial decisions on information, presented in financial statement because it enables them to identify whether data is falsified or not.

\section{References}

Bukhvalov A.V. (2008) Asimmetriya mezhdu insaiderami i autsaiderami: problema dvoistvennosti otsenki aktivov kompanii [Asymmetry between insiders and outsiders: the problem of the duality of company assets valuation]. Russian Journal of Management, no. 4, pp. 17-48. (In Russ.)

Veshkurtseva Z. (2011) Kommentariy po teme makhinatsy s otchetnost'yu [Comments on the subject of fraud with reporting]. Klub glavnykh bukhgalterov, no. 12. (In Russ.)

Edinaya baza dannykh resheniy sudov obshchey yurisdiktsii Rossiyskoy Federatsii [Unified database of decisions general jurisdiction courts of the Russian Federation]. Available at: http://xn--90afdbaav0bd1afy6eub5d.xn--p1ai/ (accessed: 27.06.2016). (In Russ.)

Informatsionno-analiticheskaya sistema FIRA PRO [Information-analytical system FIRA PRO]. Available at: http:/ www.fira.ru (accessed: 20.09.2015). (In Russ.)

Informatsionno-analiticheskaya sistema SPARK [Information-analytical system SPARK]. Available at: https://www. spark-interfax.ru/Front/Index.aspx (accessed: 27.06.2016). (In Russ.)

Kizilov A.N., Bogataya I.N. (2015) Analyz sostoyaniya i napravleniya razvitiya rynka auditorsko-konsaltingovykh uslug v Rossii [Analysis of the state and development trends of the market for audit and consulting in Russia]. Meshdunarodniy bukhgalterskiy uchet, no. 6, pp. 37-51. (In Russ.)

Kuvaldina T.B. (2015) Kovenanty: sushchnost' i raskrytie informatsii v bukhgalterskoi othetnosti [Covenants: the essence and disclosure of information in the financial statements]. Meshdunarodniy bukhgalterskiy uchet, no. 1, pp. 12-21. (In Russ.)
PricewaterhouseCoopers. Available at: http://www.pwc.ru/ $\mathrm{ru} /$ training/corporate-governance/anti-fraud-management.jhtml (accessed: 19.06.2016). (In Russ.)

Polozhenie po bukhgalterskomu uchetu 'Raskhody organizatsii' 10/1999 ot 06.05.1999 [Russian Accounting Standard 10 'Costs of organizations']. Available at: http:// www.consultant.ru/document/cons_doc_LAW_12508/ (accessed: 9.08.2016). (In Russ.)

Polozhenie po bukhgalterskomu uchetu 'Uchet osnovnykh sredstv' 6/2001 ot 30.03.2001 [Russian Accounting Standard 6 'Accounting of property, plant and equipment']. Available at: http://www.consultant.ru/document/cons_ doc_LAW_31472/71350ef35fca8434a702b24b27e57b60e1162f1e/ (accessed: 9.08.2016). (In Russ.)

Polozhenie po bukhgalterskomu uchetu 'Uchet nematerial'nykh aktivov' 14/2007 ot 27.12.2007 [Russian Accounting Standard 14 'Accounting of intangible]. Available at: http:// www.consultant.ru/document/cons_doc_LAW_63465/ adf2cfd636e9e799777ca5e7c8add8b722dced71/ (accessed: 9.08.2016). (In Russ.)

Printsipy korporativnogo upravleniya OESR [OECD Principles of Corporate Governance]. 2004. Available at: https:// www.oecd.org/corporate/ca/corporategovernanceprinciples/32159669.pdf (accessed: 10.07.2016). (In Russ.)

Ruzhanskaya L.S. (2010) Raskrytie informatsii rossiyskimi kompaniyami: rezul'taty empiricheskogo issledovaniya [Disclosure of Russian companies information: results of empirical research]. Russian Journal of Management, no. 3, pp. 35-56. (In Russ.)

Soboleva G.V., Tolkacheva D.G. (2014) Analyz vozmozhnosti vyyavleniya manipulirovaniya dannymi finansovoy (bukhgalterskoi) otchetnosti na osnovanii dannykh finansovykh indikatorov [Analysis of the possibilities to detect financial (accounting) statements manipulations on the basis of financial indicators]. Auditorskie vedomosti, no. 7, pp. 13-21. (In Russ.)

Titova S. (2011) Igry s otchetnost'yu [ Games with the statements]. Novaya bukhgalteriya, no. 4 (In Russ.)

Udal'tsov V.E., Tikhonova N.M. (2013) Vyyavlenie vliyaniya informatsionnoy prozrahnosti na zatraty na capital i effektivnost' deyatel'nosti rossiyskikh publichnykh kompaniy [Identifying the impact of information transparency on the cost of capital and the efficiency of Russian public companies]. Korporativnye finansy, no. 25, pp. 2-16. (In Russ.)

Feruleva N.V., Shtefan M.A. (2016) Vyyavlenie faktov fal'sifikatsii finansovoy otchetnosti $\mathrm{v}$ rossiyskikh kompaniykh: analiz primenimosti modeley Benisha i Roksas [Detection of financial statements fraud in russian companies: analysis of the Beneish and Roxas models applicability]. Russian Journal of Management, no. 3, pp. 49-70. (In Russ.)

Federal'niy zakon ot 30.12.2008 No. 307-FZ (red. ot 03.07.2016) 'Ob auditorskoy deyatel'nosti' [Federal law 
30.12.2008 No. 307-FZ (red. ot 03.07.2016) 'On audit activity']. Available at: http://www.consultant.ru/document/cons_doc_LAW_83311/(accessed: 29.07.2016). (In Russ.)

Ekonomicheskie prestupleniya: lyudi, kul'tura $i$ mekhanizmy kontrolya. Chetvertiy vsemirniy obzor ekonomiheskikh prestupleniy [Economic crime: people, culture and controls. Fourth Global Economic Crime Survey]. 2008. Available at: https://www.pwc.ru/ru/forensic-services/assets/ gesc_russian_supplement_rus.pdf (accessed: 19.06.2016). (In Russ.)

Beneish M. (1999) The detection of earning manipulation. Financial Analysts Journal, vol. 55, no. 5, pp. 24-36.

Dechow P.M., Ge W., Larson C.R., Sloan R.G. (2011) Predicting material accounting misstatements. Contemporary Accounting Research, vol. 28, no. 1, pp. 17-82.

Detecting fraud in financial statements: A publication from Alan D. Lasko \& Associates, P.C. 2012. Available at: http:// finance-comm.blogspot.ru/2012/03/detecting-fraud-in-financial-statements.html (accessed: 20.01.2016).

Draft of the nationwide survey 'Practice of fighting the corporate fraud' Final Report. 2014. Available at: http://www. vegaslex.ru/data/2014/04/16/ 1234640503/VEGAS\%20 LEX_Antifraud\%20survey\%20report_03.2014.pdf (accessed: 20.06.2016).

Ernst \& Young, Competing for growth: How business is growing beyond boundaries. 2011. Available at: http://www.eba. com.ua/sites/default/files/files/ members_review/EY_Globalization_3_0_2011.pdf (accessed: 02.04.2016).

Harrington C. (2005) Analysis ratios for detecting financial statement fraud. Fraud Magazine. Available at: file://C:/ Users/\%D0\%9D\%D0\%B0\%D1\%82\%D0\%B0\%D0\%BB\%D1\%8C\%D1\%8F/Downloads/ACFE\%20Article\%20 Formulas\%20for\%20detection\%20Analysis\%20(2).pdf (accessed: 05.04.2016).

Person O.S. (1995) Using financial statement data to identify factors associated with fraudulent financial reporting. Journal of Applied Business Research, vol. 11, no. 3, pp. 38-46.

Report to the nations on occupational fraud and abuse. 2014. Available at: http://www.acfe.com/rttn/docs/2014report-to-nations.pdf (accessed: 08.04.2016).

Rezaee Z. (2002) Financial statement fraud: Prevention and detection. New York, John Wiley \& Sons, Inc.

RosPravosudie. Available at: https://rospravosudie.com/ (accessed: 15.06.2016).

Roxas M. (2011) Financial statement fraud detection using ratio and digital analysis. Journal of Leadership, Accountability, and Ethics, vol. 8, no. 4, pp. 56-66.

Summers S., Sweeney J. (1998) Fraudulently misstated financial statements and insider trading: An empirical analysis. The Accounting Review, no. 1, pp. 131-146.
Tarjo, Herawati N. (2015) Application of Beneish M-Score models and data mining to detect financial fraud. Social and Behavioral Sciences, vol. 211, pp. 924-930. 